INTERNATIONAL JOURNAL FOR

HISTORY, CULTURE AND MODERNITY

www.history-culture-modernity.org

Published by: Uopen Journals

Copyright: (c) The Author(s).

Content is licensed under a Creative Commons Attribution 4.0 International Licence

elSSN: 2213-0624

\title{
To Hunt or Not to Hunt: Tiger Hunting, Conservation and Collaboration in Colonial India
}

\author{
Rajarshi Mitra
}

HCM 7: 815-839

DOI: $10.18352 / \mathrm{hcm} .587$

\begin{abstract}
As the Edwardian era came to an end in Britain and its Empire began to decline, the glorious days of tiger hunting in India were being measured against a genuine fear of the total extinction of tigers. This article maps the precarious position of Indian tigers in the hands of hunters against the rising concern over preservation of the species in the first half of the twentieth century. Ranging from the bureaucratic to the overtly sentimental and personal, these attitudes, taken together, reveal a pre-'Project Tiger' conservation milieu in colonial India. They help us to judge the cultural status and symbol of the Bengal tiger before it became an iconic species for wildlife conservation in postcolonial India. The various debates and representations of tigers in hunting memoirs often throw light on intricate socio-cultural problems threatening the survival of the cat. In fact, the debates, as much as they spread awareness, ended up strengthening the bureaucratic and sometimes political hold over Indian forests. The article further tracks imperial discourse on the systematization of tiger hunts, which was effectively linked with the preservation of tigers and collaboration with Indians. During the twilight of the British Empire, tiger hunt and tiger conservation would emerge as sites for possible collaboration between Indians and their rulers. As recent efforts at international collaboration to protect tigers have shown, the tiger retains enough sentimental value to secure bureaucratic and political ties between nations.
\end{abstract}

Keywords: British Raj, colonialism, conservation, hunting, India, tigers 


\section{Introduction}

There are some persons who doubt or dispute the progressive diminution of wild life in India. I think that they are wrong. The facts seem to me to point entirely in the opposite direction. Up to the time of the Mutiny lions were shot in Central India. They are now confined to an ever-narrowing patch of forest in Kathiawar. I was on the verge of contributing to their still further reduction a year ago myself; but fortunately I found out my mistake in time, and was able to adopt a restraint which I hope that others will follow. Except in Native States, the Terai, and forest reserves, tigers are undoubtedly diminishing. This is perhaps not an unmixed evil. ${ }^{\mathrm{I}}$

In an address delivered to the Burma Game Preservation Association on Io December I90 I, Lord Curzon, the then Viceroy of India, referred to issues which would be debated over by government officials, naturalists, hunters and Indian nationalists throughout the twentieth century. His address gave an official seal to a conservation debate that would pave the way for future game laws and wildlife preservation acts in India. In the address, Lord Curzon's magnanimous gesture to save Asiatic lions contrasts with his ambiguous attitude towards the preservation of Indian tigers. This ambiguity lay at the heart of British Raj's ${ }^{2}$ policies towards Indian tigers, leading to their widespread destruction in the twentieth century. By a popular estimation, 80,000 tigers were killed between I 875 and I $925 .{ }^{3}$ Hunter turned conservationist E.P. Gee estimated that at the beginning of the twentieth century Indian tigers numbered around 40,000 ; by I 964 only a meagre 4000 wild individuals remained. ${ }^{4}$ While tigers were tragically decimated, the population of Asiatic lions, geographically confined to Kathiawar, continued to increase and they were, therefore, saved from total extinction. Lord Curzon famously decided to save the remaining few Asiatic lions in Kathiawar by securing a sanctuary for them. He was also instrumental in founding Kaziranga in Assam, which became the first sanctuary for one-horned rhinoceros in India.

A major reason behind the destruction of tigers in British India was the mythical aura surrounding predators. Nineteenth-century big game hunters contributed to this mythology in their hunting narratives that turned the tiger into both a vermin and a prized trophy. Almost every hunter was after its life. Even though tigers were praised as majestic 
and proud creatures, they were disliked for their cannibalistic propensities. In most hunting narratives, man-eating tigers were represented as scourges haunting native villages. Moreover, hunting tigers became quintessentially part of the overall Indian experience for the British hunters, who regarded tiger hunting as a masculine blood sport requiring bravado, nerve and tact. ${ }^{5}$

Taking my cue from Vijaya Ramadas Mandala, I locate tiger hunting 'as an imperial showcasing of power in colonial India' that was 'vital' for governance and rule. ${ }^{6}$ Throughout the Raj, persecution of Indian tigers had strong official encouragement: colonial authorities periodically announced rewards to hunt down roguish tigers. From the early twentieth century onwards, efforts to preserve the Indian tiger as a game species began to emerge. During and after the World War I, as the British Raj watched India's growing nationalist movement with concern, debates around preserving tigers - now considered a national heritage - began to intensify. Discourses on the tiger were gradually transformed to suit a beast to be protected and conserved rather than hunted. This article addresses these shifts in colonial discourse on the tiger and connects these shifts with gradual modifications in the performance of tiger hunting. Different methods of tiger shooting (the way this was conducted in India) and the various socio-cultural as well as political customs attached to it had a severe impact on the population of tigers.

Tiger hunting necessitated elaborate preparation and effective collaboration between a European hunter and native shikaris (literally 'hunters' in Hindi). In the twentieth century, efforts were made by tiger hunters to systematize the collaborative performance of tiger shooting. Instead, a manageable chaos of tiger hunting continued to bear results till the twilight of the Empire when animal photography and other tourist activities took over. Tigers and tiger hunting were imbricated in a complex web of imperial discourse articulated in hunting narratives, forest bureaucracy, game legislation and racial relationships between the colonizer and the colonized. What becomes evident in hunting narratives is an imperial effort to turn tiger hunting into a systematic, normative process. This effort was spread across in discourses of imperial government structures, legislation and popular hunting narratives that recorded the effort of an individual to discipline one's performance. This article presents a range of opinions, both official and civilian, that 
influenced normative discourses on tiger hunting and tiger conservation. These opinions, in their turn, reveal the limits of a colonial state apparatus like the forest department that was trying legally to control processes like tiger hunting.

The article opens with colonial-era discussions on game laws and the need for preservation of tigers as a game species. Colonial legislation on forests and wildlife were actually meant to regulate revenue from natural environment and pacify forest tribes. In the second section, I consider exchange of capital as an important incentive for the existence of tiger hunting, despite political upheavals in British India. In the final section I look at how hunting was projected as a collaborative performance to justify the legitimacy of the British Empire in India. Here, I further draw from hunting narratives to reveal the extent to which discourses of systematization affected the nature of the tiger hunt. Since all hunts tended to become formulaic repetition of an imperial collaborative model, it often left the hunters with very little room for any creative engagement with Indian landscape.

\section{Preserving the Tiger: Debates, Conflicts and Game Laws}

From the early twentieth century onwards, efforts to preserve the tiger as a game species began to emerge. During and after World War I, as British Raj watched India's growing nationalist movement with concern, debates around preserving tigers, now considered a national heritage, began to intensify. Tiger hunting, however, continued unabated throughout the Raj. This colonial debate, in bureaucratic and public circles, on the preservation of tigers, provided a conservation rhetoric that is still in currency. The affective nature of this debate's rhetoric reflects the environmental attitude of a generation of British naturalists and bureaucrats unsure of the tiger's survival as a species. Often discussion on tigers reflected anxieties over the legacy and prestige of the British Empire and the entitlements it assured the Britons. From these anxieties stemmed a fear over lack of bureaucratic hold over Indian forests and game animals. Commentaries on game laws enacted by the Raj revealed a sense of disenchantment with the workings of the colonial state. Environmental histories of colonial India have already highlighted these patterns in piecemeal. ${ }^{7}$ Game laws and conservation 
ethics, to a certain extent, match K. Sivaramakrishnan's analysis of 'forestry' under three guises: first, 'as a set of material technologies imposed on trees ... wild animals', second, as a legal regime to extract revenue, and third, as 'a system of rational knowledge' ${ }^{8}$ Along with these three, we must add another guise: popular literature and debates within civil society regarding the importance of an animal species, in our case, tigers.

It is in the domain of the popular where the 'real' tiger and the 'imagined' or 'mythical' tiger met, and sometimes replaced one another. The real tiger was hunted because it was valued as a trophy and as a 'manly' enemy. ${ }^{9}$ Eradicating big cats like tigers was considered a colonial duty by the great white hunters posing as saviours trying to safeguard a helpless native population from a ruthless beast. Mahesh Rangarajan has drawn structural similarities between the European policy of exterminating predators like wolves and the colonial efforts at destroying tigers in India. ${ }^{10}$ Hunting and legal narratives about wolves and tigers show that there were rhetorical similarities as well. Like the wolves in Europe, tigers were demonised in India. Patrick Newman has tracked down a discourse of what he terms fictional 'weretigers' in hunting literature from European colonies in Asia. ${ }^{11}$ In hunting and conservation literature from the British Raj, the Indian tiger's primary impact remained discursive. Its image as a fierce and dangerous beast was part of a colonial discourse that elucidated a European hunter's need to intervene and restore order in the colonial forests.

Once the tiger began to be conserved, the beast became a national heritage:

The causes of this diminution in the wild fauna of India are in some cases natural and inevitable, in others they are capable of being arrested. In the former class I would name the steady increase of population, the widening area of cultivation, and the improvement in means of communication - all of them the sequel of what is popularly termed progress in civilisation. Among the artificial and preventable causes I would name the great increase on the number of persons who use firearms, the immense improvement in the mechanism and range of the weapons themselves, the unchecked depredations of native hunters and poachers, and in some cases, I regret to say, a lowering of the standard of sport leading to the shooting of immature heads, or to the slaughter of females. The result of all these agencies, many 
of which are found in operation at the same time, and in the same place, cannot fail to be a continuous reduction in the wild game of India. ${ }^{\mathrm{I} 2}$

Long before Project Tiger, ${ }^{13}$ British naturalists and administrators had held debates on the necessity of overarching theories for game preservation in India. Lord Curzon, too, was aware of human conflict arising from adapting an overarching theory for the state. He warned the legislators against devising any 'stereotyped or Procrustean form of procedure' for game preservation in India. ${ }^{14}$ What Lord Curzon had warned against in his address would, ironically, return to haunt the government in postcolonial India. When Lord Curzon had delivered his address, big game hunting in India was in the early stages of becoming a full-fledged industry. By the early twentieth century tiger hunting had become synonymous to British prestige and a symbol of ruling power. It was also emerging as an industry with tour operators and native guides making huge money by helping hunters bag kills. For the British Raj, hunting was where leisure and governance met. There was significant pressure on the colonial government to control animals destroying crops and terrorizing villages. Throughout the nineteenth century, the Raj gave away rewards on a regular basis to those who exterminated wild beasts. ${ }^{15}$

Hunting narratives from the nineteenth century are filled with selfcongratulatory anecdotes about European hunters rescuing a village from the ravages of a man-eating tiger. William Rice, one of the popular hunter-writers, made a confident plea in his preface to Tiger-Shooting on Foot to the British authorities to allow him to use his method of shooting tigers in Singapore. Rice was bent on getting rid of tigers wherever they created nuisance and wherever they hindered the onward march of the Empire. ${ }^{16}$ Most hunting stories begin with a hunter reaching a village and villagers complaining about tigers. This is followed by a narration of the hunter's heroic chase and final encounter with the beast. The body of the dead beast is then carried to the village amidst elaborate celebrations. This pattern of storytelling remained constant throughout the Raj. Depending upon the literary ability of the author and the period of composition, what varied were rhetoric and stylistics.

The celebratory tone of hunting narratives was occasionally marred by periodic warnings about local decimation of game due to deforestation and over-hunting. From the early twentieth century onwards, anxieties over dwindling game became a constant refrain in otherwise 
self-congratulatory hunting narratives. G.C. Aflalo gave vent to this anxiety in his hunting book published in the early twentieth century. In his Sportsman's Book for India - a well-researched hunting manual for big game hunters - he wrote that the European hunters had to give up their dreams of becoming colonial heroes by rescuing villagers from man-eating tigers in India. The population of tigers had come down drastically, and the only game to be had was in 'comparatively restricted areas'. He went on to list the reasons for such a sorry state of affairs: deforestation, increased accessibility to hunting areas because of the railways, spread of agriculture and improved firearms. If tigers were found anywhere in substantial quantities then they had been preserved either by geographical conditions or by native chiefs. ${ }^{17}$

Subsequent hunting memoirs and manuals testifies that tigers and other game animals were better preserved in forests under native states than in British India, a fact that Lord Curzon did not acknowledge in his address. He felt 'the question of Native States' complicated the matter of game protection further. ${ }^{18}$ Laws enacted by the Raj were not applicable in the princely states of India, where laws of ownership of forest, land and animals were locally negotiated. The native states had their indigenously developed hunting culture and a hunting iconography drawn largely from Mughal and local traditions. They jealously guarded animals in their forests. ${ }^{19}$ For the forests in British India, where the conservation of tigers was more than a matter of local concern, ownership claims gave rise to ideological battles between forest dwellers and the Raj. ${ }^{20}$

Official efforts to preserve Indian forests in the nineteenth century paralleled the government's initiatives to save Indian fauna. By the early twentieth century, imperial forestry had become well established in India. Trees had been scientifically analyzed, and forest covers properly mapped for economic use. The government, to the regret of colonial naturalists and administrators, had yet to decide on animals within the forests. Whatever laws existed before World War I were not strong enough to save game animals in a politically diverse country like India. The Elephant Preservation Act of I 879 had protected elephants because they were captured and employed in heavy hauling work. The Act had ensured a strong bureaucratic hold over wild elephant population. It was followed by Wild Animals and Birds Act I 887, and its much augmented version in I9I2: the Indian Wild Birds and Animal Protection Act. 
The move to control game intensified during the early twentieth century especially after World War I. Internationally, and within the British Empire, pressure groups advocating stronger game laws and humanitarian treatment of animals had become better organized. Edward North Buxton's industrious propaganda led to the formation of Society for the Preservation of the Wild Fauna of the Empire in I903. The society boasted an array of influential members with vast networks in the Empire. ${ }^{21}$ Initial issues of their journal, first published in I903, reviewed game laws in Africa and drew colonial government's attention to the condition of the fauna in the Empire. They published reports on annual kills in shooting blocks, permissions of game licenses, letters by well-wishers and the society's day to day activities. A major concern of the members was the unavailability of game for hunting. Wild life was termed 'heritage of the Empire', best preserved in sanctuaries with strict game laws. ${ }^{22}$ The group was able to garner enough international support to bring about a period of intense colonial legislative activity throughout Africa. But game laws and vigilantism by private imperial groups like the Society for the Preservation of the Wild Fauna of the Empire had little impact on widespread hunting. The laws ended up being badly implemented because of the paucity of funds and because of the impossibility of policing large areas. Of course, the laws harassed the Africans, who, nonetheless, to the chagrin of the European settlers, continued to 'poach' animals. Owing to the complexities regarding the implementation of game laws, frustrations rose among conservation groups. These laws harried Africans, who found that the white settlers merely used these laws to fence their territory and hedge in game. ${ }^{23}$

In India, wildlife preservation acts were enacted by the Raj as a response to a pan-Empire trend to conserve game animals and secure hunting privileges. The Acts contained sections suggesting restrictions over number of games killed by any hunter, rules for open and close seasons, and protection of specific species. However, the Act of I9I 2 was immediately criticized by foresters for its structural weaknesses. E.P. Stebbing, an influential British forester and entomologist, remarked in his Diary of a Sportsman Naturalist that sections of the Act were too vague and ambiguous. The Act had put the onus on local governments to decide on open and close seasons and the number of game killed. This, he believed, in a land of excessive entitlements like India, would create added confusion. ${ }^{24}$ It was difficult for the government to 
implement the laws, because foresters were already overloaded with work, and because hunting animals was still looked upon as a privilege, which, if denied, might offend anyone of some social standing. Therefore, local governments, despite revising their game laws and establishing sanctuaries, found it difficult to stop hunters from flouting rules. Stebbing was not in favour of blaming European hunters solely for the diminution of Indian game. He regarded native shikaris (hunters) as inveterate poachers, and castigated native licensed gun holders as severely lacking in hunting etiquette. The result of all this, he believed, was a free-for-all shooting season all the year round. ${ }^{25}$

In protected forest reserves, colonial bureaucracy often elbowed out forest dwellers who had a right to hunt for subsistence. Game preservation laws were implemented in the same way law was used by the forest department to cordon off valuable timber inside the forest. These restricted local people's traditional access to the forest with the express result that hunting became an elite practice governed by a complex web of entitlements and ownership claims. ${ }^{26}$ Stebbing said about the ownership of animals:

It must be remembered that the old-time rulers in India were the de facto owners of all the animal inhabitants thereof. The Government of India are the present owners, and therefore, have every right to safeguard this valuable property. They have done so in the case of the forests. But they have been slow to realise the value of animals and the fact that a very reasonable profit can be made out of this valuable asset.

The native of India has never made any claim to the ownership of game animals (mammals) or birds, since he has never possessed it. He only asks that his crops should be protected against the depredations and legislation which will do this will never be resented. ${ }^{27}$

Stebbing proposed elaborate game laws for forests in British India. Forests were to become game sanctuaries with rules on the opening and closing of shooting seasons. Game should be shot with prior permission and shooting licenses should be charged according to the importance of the game in the hunting hierarchy. For example, a tiger that had turned into a cattle lifter and a scourge should have a higher price tag. ${ }^{28}$ Following World War I, publications advising hunters to shoot big game in India provided an overview of game laws passed by the 
Government of India and the native states. W.S. Burke appended an extensive list of game legislations in the princely states and British India provinces in his Indian Field Shikar Book. It seems that illegal hunting perversely allowed the native states to collect extra revenue. The princely states of Gwalior, Indore and Dholpur mentioned curbs on tiger shooting. However, except for tigers most animals (including birds and herbivores) were protected by close seasons. In Dholpur the penalty for shooting or capturing a tiger or tigress without a license was 200 rupees, whereas in Gwalior the penalty for shooting any beast, including tigers, was 50 rupees. Burke had further included formats for hunting license applications to the native durbars and British India provinces. ${ }^{29}$

\section{Economy of the Tiger Hunt}

From Burke's hunting manual it becomes quite evident that by the I920s hunting animals, especially prized trophies like wild tigers, had become a profitable business for the hunt organizers and the forest departments in British Indian provinces and the princely states. As the hunting culture became more business-minded, it started associating hunting ethics and game preservation with the economic value of game. Tiger hunting was always a capital-intensive practice. In the twentieth century dwindling game meant that animals available for hunting became scarcer; it therefore became imperative to control hunting entitlements with a heavier price tag and penalty. Hunting books frequently debated the need for ethical hunting. C.H. Stockley's Big Game Shooting in the Indian Empire mentioned in his introduction that hunting etiquette and conservation ethics had 'changed in favour of the game' in India, and that only malefactors indulged in mass illegal slaughter. ${ }^{30}$ In India, pressure groups had gradually emerged to advocate greater control over game animals. Founded in I 886, the Bombay Natural History Society (BNHS) was instrumental in disseminating knowledge about India's natural history at a time when game was dwindling all over India. Its subsequent surveys of Indian fauna would help in classifying animals and proposing measures to save them.

Often, individual foresters like Stebbing expressed the aspirations of a pressure group by publishing their hunting memoirs with detailed 
comments on the game laws and the condition of fauna in British India. A few months before the Act of I9I2 was passed, Stebbing had published a long article in the Proceedings of the Zoological Society of London, reviewing the state of game preservation in British India by area. He suggested separate measures for game preservation in, among others, the United Provinces, Punjab, Hyderabad, Kashmir and NorthWest Frontier Province. ${ }^{31}$ Stebbing was, however, keenly aware of the emerging hunting industry in India. The industry, though disorganized, served various sectors: tourism, hospitality, gun manufacturing and publishing.

By I920, when the industry had become quite extensive, Stebbing included a long chapter titled 'The Economic Value of the Fauna' in his Diary of A Sportsman Naturalist. He argued that the Forest Department in India needed to treat animals as products of the forests and preserve them accordingly for the profitable big game hunting trade. Along with the revenue generated from hunting licenses, he wanted the government to formalize a disorganized but widespread trade in skins, flesh and other valuable body parts of the wild animals. ${ }^{32}$ The trade in animal body parts was already flourishing in some parts of India. In the prosperous south Indian state of Mysore, Eugene Melville Van Ingen had set up a booming business in taxidermy in I9I2. The company was successful enough to process 43,000 tiger skins during the years of its operation. ${ }^{33}$ Owing to the huge popularity of tiger hunts, advertisements for tiger shooting were common. In I904, a colonial Indian newspaper advertised high velocity 'Cordite Rifles' as perfect weapons to shoot tigers. ${ }^{34}$ Hunting books used to flash similar advertisements in their appendix section, depicting the embeddedness of hunting in the imperial leisure economy.

Given the pastoral character of the Indian economy during the British Raj, ${ }^{35}$ hunting always generated employment for a section of villagers who, when hunters encamped, could be engaged as beaters, trackers, servants, gun carriers and cooks. Film footage from the period shows elaborate preparations for tiger hunting. Some of these films established a visual pattern for the familiar imperial symbolism of colonial hunts. The silent movie Tiger Beat (I937) depicts how a British officer engages the entire village in driving a troublesome tiger out of the forest. Long shots show the officer holding parley with the villagers, who, working under his instruction, cross a river and beat the 
forest. Involvement of a retinue of men and large animals like elephants meant that hunting books became more management-conscious in their counsel. Late-nineteenth-century publications had begun advising readers on the proper management of hunting expeditions. James Moray Brown's Shikar Sketches, with Notes on Indian Field Sports had tables on wages for servants and beaters. ${ }^{36}$ Almost forty years later, Stockley's Big Game Shooting in Indian Empire, with price lists, estimation charts and wage tables for Indians under the hunter's employ, similarly pointed out to readers the need to effectively economize and manage hunting expeditions. Because they tended to be 'how-to books', hunting books contained fairly scrupulous notes on the preparation and management of tiger hunts. Stockley advised tiger hunters to manage bakshish (rewards) to Indian shikaris and servants by measuring the trophies at the end of the hunt. He offered five rupees for an ibex with forty inch horns, and two rupees 'for every inch over that length'. His personal servant got an extra five rupees a month. The coolies' reward was based on the level of difficulty of their work. ${ }^{37}$

Tiger hunting narratives regularly reflected on the effect of tiger hunting on the Indian economy. James Inglis appended a long article from Saturday Review of I 5 January I 887 that put tiger-related death toll to 22,907 in the current year. ${ }^{38}$ Statistical records on the loss of human lives, cattle and profit implicitly judged the ineffectual and passive nature of natives who faced a superior, evil force like the tiger. These records therefore had the effect of denigrating the native population, and were used as a reason for teaching Indians self-reliance.

However, when popular literature celebrated tiger hunting, conservation-minded foresters denounced it in their writings:

To represent the normal tiger as destructive vermin, the plague of the country-side, 'cuts little ice' with those who know. I am also sceptical of the annual figures representing humans killed by tigers. Moreover, the tiger has his definite place in Nature's scheme, and keeps down the rapidly multiplying numbers of crop-destroyers such as pig and deer. When I hear the multitiger man enlarging on the need of 'keeping down tigers' I always wonder what he does with his skins. What is one to do with even fifty tiger-skins? Where is he or his relatives and friends going to put them all? I take it that no true shikari ever contemplates that foul crime, the turning of trophies into money. ${ }^{39}$ 
F.W. Champion, a forest officer from the United Provinces in north India, was committed to changing the perception of tigers as cruel and dangerous beasts. Champion was also the first wildlife photographer to have worked extensively in Indian forests. In his memoirs and articles, which he contributed to natural history journals, he took up the cause of the tiger and made several arguments against the 'alleged' cruelty of tigers. In an article written for the magazine India in I930, he gave matter-of-fact arguments such as: 'We human beings also kill other animals because meat is an important item of our food, although we can live without it, whereas the tiger simply cannot exist on a vegetarian diet' ${ }^{40}$ Later, in an article on game preservation in the United Provinces, Champion would claim that the number of tigers had increased in the province owing to better conservation. However, he would suggest a very strict code of game preservation: 'to limit the number of tigers allowed to be shot to one per gun each year'. ${ }^{41}$

Champion's cause was later taken up by one of his friends, Jim Corbett, who became famous in the United Provinces for his hunting exploits. To Corbett we owe expressions like the 'tiger is a large-hearted gentleman with boundless courage'. ${ }^{42}$ In the early I930s, he argued under the title 'Why the Tigers become Man-eaters' that human beings were not the natural diet of the tigers, who only took to man-eating when under extreme physical stress. Neither were tigers bloodthirsty, cruel and dangerous; they were shy and proud beasts, slowly losing their natural prey base due to overhunting. Both Corbett and his friend, Champion, were instrumental in founding Hailey National Park in the United Provinces under the National Parks Act passed by the government in I935. In an article on the park in I94I, Champion outlined the aims and objectives of the park. By restricting human access to the game, he imagined a vibrant ecosystem for the future generation. What becomes clear is the arrival of a new tiger: a tiger required by a new kind of forest and shikar bureaucracy bent on conservation in India. The old image of a cruel and bloodthirsty beast had to be transformed into a tamer beast for national parks catering to the travel industry:

The tigers (in the park), so far, are much the same as they were before, although they are quite often to be seen at a distance in the daytime. In due course, when a new generation of tigers that have never been hunted grows up, it is more than likely that the tigers will carry on their daily life 
regardless of the presence of human beings, in a way that lions are now to be seen doing in the national parks of Africa. ${ }^{43}$

In forests controlled by British India, foresters strongly suggested restricting the access of natives to game. To stop poaching, native shikaris were to be strictly dealt with and the open sale of meat of wild animals stopped. Champion echoed Stebbing when he suggested that several steps be taken to stop access to Reserved Forests that were under government care. Gun licenses were to be divided into licenses to hunt game and licenses to preserve crops, while motor cars were to be restricted from entering the forests. In fact, hunting from motor cars became a burning issue after World War I. Motor cars provided easy access to game and greater mobility to hunters, who were now equipped with better weapons and headlights of cars to hunt at night. Champion suggested that the government should impose penalties on those killing rare animals and that rewards for killing troublesome beasts must be given sparingly. In other words, financial encouragement to hunting was gradually to stop. ${ }^{44}$

Despite strong opinions favouring the preservation of game, the colonial forest department failed to curb widespread destruction of fauna. Disenchantment with bureaucratic bottlenecks around hunting and conservation was reflected in the writings of many sportsmen. Of course, the official voice sometimes tried to sound positive. As Deputy Conservator of Forests in the United Provinces (UP), Champion wrote two articles in The Field and in the journal of BNHS respectively observing that the situation in the forests of the United Provinces was not abysmal. He admitted that the fauna had decreased in number, though not yet significantly; what had increased was the common perception among Indians and colonial officers regarding the need for conservation of wildlife. 45

But not all the naturalists shared the view held by Champion. The naturalist Stanley Jepson gives us a glimpse of the situation in British India in his Big Game Encounters. Jepson took an overwhelmingly negative view of game preservation in India and upbraided the government for 'laissez faire' policy and lack of interest in wildlife conservation. By laissez faire, Jepson meant a complete lack of government control over game hunting, and hence private players, both British and Indian, could exploit the game the way they wanted. ${ }^{46}$ In the government circles it 
was a hotly debated topic as well. Officials like Champion were against the formation of a separate game department to enforce game laws. Champion believed that the forest department itself was capable of preserving its animal resources. ${ }^{47}$ Game laws no doubt were a huge burden on the forest officials, who were now required to issue game licenses and control entry to the forests. Sainthill Eardley-Wilmot, who was Inspector General of Forests in India during the early twentieth century, had written about the 'bitterness and jealousies' arising from enforcement of game laws. ${ }^{48}$

Due to the game laws and conservation ethics the hunting industry struggled in post-independent India. The hunting lobby, comprising of landlords, princes, travel agents and hunting companies, argued against banning of hunting citing the loss of foreign revenue. ${ }^{49} \mathrm{~A}$ few years before hunting was banned in India, Colonel Kesri Singh, Officer-inCharge of the Hunting and Shooting Department in Gwalior and Jaipur states, wrote in his memoir that he felt opinion against hunting to be peculiar and emasculating. ${ }^{50}$ Nor was he pleased with groups protesting against Queen Elizabeth II's tiger hunting trip to India in I960 because: 'There was nothing wrong in the Queen's accepting to shoot a tiger when the world knows that offering a tiger-shoot to a distinguished guest is traditionally a part of Indian hospitality'. ${ }^{51}$ The laissez faire system, which allowed such 'Indian hospitality' to exist, was also responsible for the uneven distribution of game in Indian forests. Jepson in his memoir in 1936 mentioned how in forests controlled by the British government the number of game had fallen, whereas in forests owned by native landlords numbers had increased..$^{52}$ In reality, enforcing the laws was a huge task, because all the departments capable of enforcing game laws like the police and the forest department lacked resources and were overloaded with work. Moreover, they seemed to be unwilling to enforce what seemed to be unpopular game laws, bringing them in direct conflict with both European hunters and native poachers. Game laws were a direct assault on laissez faire policy of managing game and they increased bitterness and jealousies between the officials and hunters as the century wore on. Sentiments for entitlements were so strong that even E.P. Gee, a vehement supporter of game sanctuaries and anti-hunting laws, when asked by Kesri Singh about the Queen's tiger shooting expedition in I960 replied that since tiger was not a protected species in India, hunting by the Royal Party should not be 
frowned upon..$^{53}$ Until the ban on hunting in 1972 , both the colonial and the post-colonial Indian government continued to follow a laissez faire policy in managing game.

Within the confines of imperialism, tiger hunting had to be adapted to the ethical demands of game preservation. Since tiger hunting was an experience in which there was considerable cultural investment, it continued to serve various imperial functions beyond the obvious symbolism of British intervention in Indian wilderness. In fact, hunting was central to exploring British proximity to natives. Hunting reinforced racial hierarchy and normalized the colonizer-colonized relationship. Hunting narratives, however, put forward collaborations as successful strategies of the imperial presence in India.

\section{Collaboration and Systematization}

Whereas the British sportsman brings money into a district, and in nine cases out of ten, helps to foster a better feeling between European and Indian tending to counteract the evil influences of sedition, the native shikari sits up over a water hole or beside a jungle path, slaying hind or fawn without thought of anything but the meat and hide...${ }^{54}$

The native shikari, indispensable for his local knowledge, was both praised and castigated by the European hunters. Earlier hunting narratives, like the one written by William Rice, paid glowing tribute to the extraordinary courage and nerve 'constantly displayed by' native shikaris in 'alarming situations' ${ }^{55}$ But as game became scarce, native shikaris were grossly blamed for indiscriminate poaching. Tiger hunting, in its colonial form, always made an effort to promote goodwill and collaboration between Europeans and Indians. Captain Forsyth, who in the nineteenth century had hunted extensively in the central highlands of India, suggested methods of collaborating with the natives. He reasoned that hunting was a method of surveillance and a way of ending the seclusion of the forest tribes. He claimed to have organized hunts to collaborate freely with the natives in organizing shoots, collecting information and buying provisions. He also warned against misbehaving with the locals, and advised against asking for too much from native villagers. ${ }^{56}$ 
Forsyth had further compared hunting in Africa with that of India and found the latter much improved in terms of facilities and sport offered to the Europeans. ${ }^{57}$ Several journals on natural history and sports carried articles on the efficiency and relative comfort of tiger shooting practices in India. National Geographic, for example, published a well-illustrated article in its November I 924 issue by Brigadier General William Mitchell, on how he spent his vacation hunting tigers in India with the Maharaja of Surguja. It was common for Indian princes to open their private hunting reserves to European and American guests. Princes were known for using hunting or shikar as a method of negotiation with the British officials. Further, there is reason to believe that game laws in private hunting reserves of Indian princes were better enforced. From what Brigadier Mitchell writes, we can sense a clear bureaucratic tug of war between Indian princes and British officials:

A great deal of preparation has to precede a tiger hunt. To begin with, all hunting rights in the native states are jealously guarded by their princes and no strangers can hunt without permission. The ruling British officials hesitate to ask these princes to organize hunts for anyone, because it amounts to an order, and not only makes the princes feel that their affairs are being interfered with, but that they have a right to ask favors in return..$^{58}$

In recent years, various commentaries on the limits of a colonial hunter's control over the hunt have pointed out gaps in the imperial discourse of hunting. ${ }^{59}$ This reinforces the conclusion that hunting was never a one sided affair, and Indians were active participants in imperial hunts. A discussion on native reactions to colonial hunting is beyond the scope of this essay. However, the presence of Indians meant that it was common to experience unease while organizing tiger shooting. There are instances of villagers becoming totally non-cooperative and withholding information about game from British hunters. ${ }^{60}$ Yet, every hunting narrative contained chapters on managing native collaborators while hunting, which reveals the extent to which tiger hunting narratives aimed at systematizing collaborative strategies.

The early twentieth century saw numerous hunters trying to systematize the chaos that was a tiger hunt. J.E.M. Mackenzie, who analyzed big game hunting as an imperial discourse, classified the hunting techniques of the British in colonial India using three standards: the 
geographical terrain where a hunt was conducted, the method used and the objective of the hunt. Hunting methods changed with the geographical location of a hunt. In plain lands hunting could be done on foot, whereas on difficult terrain and in dense jungles elephants were used. Methods included shooting with guns, pig sticking, baying with dogs, etc. The purpose of hunting was either recreation, defence of livestock and crops in case of deer and bison, or supplying meat to the troops. ${ }^{61}$

For the tiger hunt itself there were three techniques, combining method and purpose. Tiger hunting was generally carried out from the machan (a resting place on a tree). A few courageous tiger hunters went on foot and helped in the manoeuvre with the beaters. The third and costliest practice of tiger hunting for sports was hunting from the back of an elephant with a huge array of beaters. ${ }^{62}$ Every step leading to the killing of the beast was classified, explained and verified through individual experience. These descriptions were openly prescriptive and the intention was either to prepare the readers, who might be young hunters, to face the challenges on the field or, in the case of veterans, to rouse their memory and to elicit their judgement of the hunter-author. Hunters needed provisions to stay inside the forest, servants to look after them and native informants to liaise with the villagers and forest dwellers for information on tigers. H.Z. Darrah, shooting in Kashmir in the late nineteenth century, had suggested a long list of provisions for hunters in Indian forests. ${ }^{63}$ Darrah also shared information on native guides, shooting blocks and shops providing tents and furniture on rent. Despite efforts at systematization, tiger hunts remained as chaotic as ever, often leading to injuries and failures. F.C. Hicks, a forester at the turn of the century, suggested that tiger hunting be theorised and systematized and wrote a huge volume titled Forty Years Among Wild Animals of India, in which he claimed to have shot several tigers using his systematic methods. Systematization was to stop Europeans from being duped by native shikaris and guides and make sure that their hunting expeditions were properly planned. ${ }^{64}$

Foresters bent on preserving tigers had to work against a longstanding and popular tradition of tiger hunting. Many would use similar methods to obtain not a dead tiger but tiger photographs. Conservationminded foresters like Champion wanted to transform the methods of collaboration between Europeans and natives. Being a photograph enthusiast, Champion had used elephants and beaters to manoeuvre 
tigers to obtain unforeseen shots of them in the wild. Both Champion and Corbett had proposed widespread propaganda to earn the goodwill of the natives to save tigers. In fact, Champion had even claimed that the government, ably assisted by an influential forest official and greatlandlords, had been able to reduce poaching in the United Provinces. ${ }^{65}$

\section{Conclusion}

The imperial discourse on tiger hunting, this essay has shown, adapted to various shifts in the colonial perception of tigers. The discourse addressed these shifts in opinion by promoting conservation and by showcasing hunting as an effective means of collaboration with the natives. From the beginning of the twentieth century there was a sustained effort to systematize hunting as sports and as an imperial performance that symbolized good governance and rule. Tiger hunting's association with imperial governance also meant that it became part of a culture of imperial entitlements that made efforts to preserve the tiger as a species that stood in an ambiguous relation to man. What emerges through debates and records on tiger hunting is a noticeable distance between legal discourse and practice. Stricter game laws ran parallel to a burgeoning hunting industry in colonial India.

Despite various hurdles to game preservation, whatever forest cover is left in India today is because of the debates that began in the colonial era. Valmik Thapar's edited volume on Indian wild tigers acknowledges the debt we owe to colonial debates on game preservation. Project Tiger in 1972 inherited many of the colonial debates around conservation and faced similar problems in implementing conservation laws all over India. While trying to restrict access to animals and forests, the government came in direct conflict with the forest dwellers, often leading to violent repercussions.

In conclusion, it is pertinent to return to the four 'guises' this article has partially drawn from Shivaramakrishnan's framework on forestry, in order to understand game laws. First, as a set of material technologies, game laws in India were meant to control human access to game. In reality, however, there existed a wide gap between the legal discourse and the implementation of laws. They definitely alienated the local population by allowing forest officials to supervise access to game. The 
laws further led to debates within the government, and several forest officials and naturalists voiced their concern for the ambiguous nature of the legal discourse, which, they argued, incapacitated the authorities from saving game from destruction. When it came to game preservation, the Government of India was accused of following a laissez faire system, and in many cases it actually did so, if only to avoid being dragged into debates over privileges and entitlements. Game preservation, throughout the Raj, would have to struggle in an imperial environment of such privileges and entitlements, from the privileging of lions over tigers by Lord Curzon to letting local governments interpret game laws as they deemed necessary, to letting political guests hunt tigers freely in the forests. The material technologies supporting the implementation of game laws seemed to differ in British India and the princely states, where, owing to the monarchical nature of authority, game was better managed though injunctions and social customs.

Second, game laws allow us to explore the economy of hunting in colonial India. Largely disorganized, there definitely was a steady market for game. Occasional opinions about organizing the market were generally ignored by the government. There was demand for good products as well, since private enterprises like Van Ingens of Mysore had reaped considerable harvest from their taxidermy trade in a princely state. Hunting further generated employment for villagers living near a forest where hunters encamped. However, the hunting culture advocated a strict flow of capital from the imperial master to the servant. As for the political economy of the hunt, generations of colonials applauded its pacifying and collaborative nature. Everyday activities of the hunt were steeped in the imperial culture of the Raj, a culture that maintained and replicated the racial hierarchy at several levels.

Third, the game laws as a set of rational knowledge conditioned the conservation sentiments of later generations of foresters, both in colonial and postcolonial India. Finally, tiger hunting was part of a popular leisure culture that was built upon a perception that hunting was a noble and glorious sport. Conservationists were eager to address the gap between the real and the imaginary tiger to transform the public perception in favour of the beast. Tiger conservation went through major hurdles in colonial India because of age-old perceptions, the hunting bureaucracy and imperial entitlements. Conservationists struggled with the existing laissez faire policies of game control, the bureaucratic 
burden of game laws and the structural racism inherent in the colonial workings of the state. Many conservationists not only wanted to change the perception of tigers, but also the physical processes by which tigers were approached in the wild. They wanted to transform elaborate tiger hunting processes into something benign, like wildlife tourism and wildlife photography.

\section{Notes}

I Lord Curzon, 'Burma Game Preservation Association, December I0, I90 I', Lord Curzon in India: Being a Selection from his Speeches as Viceroy and Governor General of India I898-I905 (New York, I906) 435-36.

2 The two hundred years of colonial rule in Indian history, beginning in I757 and ending in 1947, when India won her independence from Britain, is popularly known as the British Raj or Crown Rule in India. During the first hundred years of the colonial rule, India was governed by the East India Company. Following the Sepoy Mutiny in I857, the East India Company was liquidated and India came under direct rule of the British Crown. Geographically as well as politically, the Raj consisted of provinces under British India and areas marked under princely or native states. At the time of India's independence, there were more than 550 princely states in the subcontinent.

3 Mahesh Rangarajan, India's Wildlife History (Delhi, 200I) 32.

4 E.P. Gee, The Wild Life of India (London, 1964) 57.

5 A range of scholars have pointed out that the representation of tigers in colonial texts served imperial interests. See Joseph Sramek, 'Face Him Like a Briton: Tiger Hunting, Imperialism, and British Masculinity in Colonial India, I800-I875', Victorian Studies (2006) 659-80; Ralph Crane and Lisa Fletcher, 'Picturing the Indian Tiger: Imperial Iconography in the Nineteenth Century', Victorian Literature and Culture 42.3 (20I4) 369-86; William K Storey, 'Big Cats and Imperialism: Lion and Tiger Hunting in Kenya and Northern India, I898-I930', Journal of World History 2.2 (I99I) I35-73. The literature further includes: John Mackenzie, Empire of Nature: Hunting, Conservation and British Imperialism (Manchester, I988) I79-96; Harriet Ritvo, The Animal Estate: The English and Other Creatures in the Victorian Age (Cambridge 1987) 243-88; Pablo Mukherjee, 'Nimrods: Hunting, Authority, Identity' The Modern Language Review I00.4 (2005) 923-39. 
6 Vijaya Ramadas Mandala, Shooting a Tiger: Big-Game Hunting and Conservation in Colonial India (New Delhi, 2019) 2.

7 Mahesh Rangarajan and K. Sivaramakrishnan (eds), India's environmental history: Colonialism, Modernity and the Nation: A Reader (2 vols; New Delhi, 2012); Swati Shresht, 'Sahibs and Shikar: Colonial Hunting and Wildlife in British India, I800-I935', unpublished PhD dissertation, Duke University, 2009.

8 K. Sivaramakrishnan, Modern Forests: Statemaking and Environmental Change in Colonial Eastern India (Stanford, I999) 3.

9 Heather Schell argues that behind the kinship felt by male white hunters for wild tigers lay the assumption that masculinity was in essence predatory and Darwinian. Schell, Heather, 'Tiger Tales' in Martin A. Danahay, Deborah Denenholz Morse (eds), Victorian Animal Dreams: Representations of Animals in Victorian Literature and Culture (Hampshire, 2007) 229-48.

Io Mahesh Rangarajan, 'The Raj and the Natural World: The Campaign against "Dangerous Beasts" in Colonial India, I875-I925', Mahesh Rangarajan and K. Sivaramakrishnan (eds), India's Environmental History. Colonialism, Modernity and the Nation: A Reader (2 vols; New Delhi, 20I2), I, 95-I42.

I I Patrick Newman, Tracking the Weretiger: Supernatural Man-eaters of India, China and Southeast Asia (London, 2012).

I2 Curzon, 'Burma Game Preservation Association, December Io, I90i', 436.

I3 The Government of India's Project Tiger considered tiger as an apex ('indicator') species, because, as the argument went, a tiger's presence in a forest indicated that the ecosystem was intact, therefore, it had to be conserved. The project proposed the creation of an undisturbed core area for the animals surrounded by a buffer zone where minimum human activity was allowed. In 1973 the project had designated nine reserves across the country for the protection of the big cats and had done away with all arbitrary entitlements and privileges for human interference in the tiger habitats.

I4 Lord Curzon, 'Burma Game Preservation Association, December Io, I90 I', 438.

I5 Rangarajan, India's Wildlife History, 22-5.

I6 William Rice, Tiger-Shooting on Foot (London, I857) x. 
I 7 F.G. Aflalo, The Sportsman's Book for India (London, I904) 3-4.

I 8 Curzon, 'Burma Game Preservation Association, December Io, I90I', 438.

I9 Julie E. Hughes, Animal Kingdoms: Hunting, the Environment, and Power in the Indian Princely States (Cambridge 2013).

20 Ajay Skaria, Hybrid Histories: Forests, Frontiers and Wildness in Western India (Oxford, I999); Gunnel Cederlöf, Ecological Nationalisms: Nature, Livelihoods, And Identities In South Asia (New Delhi, 2005).

2 I David K. Prendergast and William M. Adams, 'Colonial Wildlife Conservation and the Origins of the Society for the Preservation of the Wild Fauna of the Empire', Oryx 37.2 (2003) 25 I-260.

22 Introduction to The Journal of the Society for the Preservation of the Wild Fauna of the Empire (1904) I-IO.

23 Mackenzie, Empire of Nature, 200-22.

24 E.P. Stebbing, Diary of a Sportsman Naturalist in India (London, I920) 27I-73.

25 Ibid., 259-64.

26 Richard P. Tucker, A Forest History of India (New Delhi, 20I2) xv.

27 Stebbing, Diary of a Sportsman Naturalist in India, 263-64.

28 Ibid., 259.

29 W.S. Burke, Indian Field Shikar Book (Calcutta, Simla, I928).

30 C.H. Stockley. Big Game Shooting in the Indian Empire (London, I928) 4.

3I E.P. Stebbing, 'Game Sanctuaries and Game Protection in India', Proceedings of the Zoological Society of London 82. I (I9I2) 23-55.

32 Stebbing, Diary of a Sportsman Naturalist in India, 282-7.

33 March Allum, Allum's Antiques Almanac 2015: An Annual Compendium of Stories from the World of Art and Antiques (London, 20 I 5).

34 Susie Green, Tiger (London, 2006) 6I.

35 Dietmar Rothermund, An Economic History of India (Routledge, 2002) 60.

36 James Moray Brown, Shikar Sketches, with Notes on Indian Field-Sports (London, I 887).

37 Stockley, 'Big Game', 5-16.

38 James Inglis, Tent Life in Tigerland (London, I892) 35-6.

39 Colonel A.I.R. Glasfurd, 'Various Musings' Valmik Thapar (ed.), Saving Wild Tigers, I900-2000: The Essential Writings (Delhi, 200 I) 59-68. 
40 F.W. Champion. Tripwire for a Tiger: Selected Works of F.W. Champion (Chennai, 2012) 77.

4I Ibid., I I7.

42 Jim Corbett, Maneaters of Kumaon (New Delhi, I944) Xv.

43 Champion. Tripwire for a Tiger, I82-I83.

44 F.W. Champion, 'Preserving Wildlife in the United Provinces', Thapar (ed.), Saving Wild Tigers, I900-2000, 59-68.

45 Champion. Tripwire for a Tiger, I I5-I 22.

46 Stanley Jepson, 'An Appeal for the Preservation of Wildlife' in Thapar (ed.), Saving Wild Tigers, I900-2000, 8I-92.

47 Champion, 'Preserving Wildlife in the United Provinces', 6I-8.

48 Sainthill Eardley Wilmot, 'Of Forests and Foresters', Thapar (ed.), Saving Wild Tigers, I900-200O, I5.

49 Kailash Sankhala, 'The Skin Trade', Thapar (ed.), Saving Wild Tigers, I900-2000, I 57-68.

50 Kesri Singh, Hints on Tiger-Shooting (Bombay, I969) xiv.

5 I Ibid., xvii.

52 Jepson 'An Appeal for the Preservation of Wildlife', 83.

53 Singh, Hints on Tiger-Shooting, xvii.

54 Ibid., 4.

55 Rice, Tiger-Shooting on Foot, vii.

56 James Forsyth, The Highlands of Central India (London, I87I) IOI, 275-6.

57 Ibid., 442-5.

58 William Mitchell, 'Tiger Hunt in India I924', National Geographic Magazine 46:5 (I924) 545-598 (https://news.nationalgeographic.com/ news/20I4/o8/I40803-tiger-hunt-I924-india-maharaja-safari/, accessed I 7 November 20I6).

59 Ezra D. Rashkow, 'Making Subaltern Shikaris: Histories of the Hunted in Colonial Central India', South Asian History and Culture 5.3 (20I4) 292-3 I3.

60 Ibid., 300-5.

6I Mackenzie, Empire of Nature, I69-70.

62 Ibid., I80-I.

63 H.Z. Darrah, Sports in the Highlands of Kashmir (London, I 898) 44I.

64 F.C. Hicks, Forty Years Among Wild Animals of India (Allahabad, I9Io).

65 Champion, Tripwire for a Tiger, I I5-22. 


\section{About the Author}

Rajarshi Mitra is an Assistant Professor in the Department of Humanities and Social Sciences, Indian Institute of Information Technology, Guwahati, India. Before joining IIIT Guwahati, he was Assistant Professor in the Department of English, Central University of Karnataka. He has a PhD (20I4) from the English and Foreign Languages University, Hyderabad, on natural history narratives from India between I 857 and I950. His research interests include food culture, Romanticism and colonialism. E-mail: mitrarajarshi24@gmail.com. 